\title{
Evaluation of Bacillus spp. as dough starters for Adhirasam - A traditional rice based fermented food of Southern India
}

\author{
Anvar Hussain Noorul Anisha ${ }^{1}$, Rangasamy Anandham ${ }^{2}$, Soon Woo Kwon ${ }^{3}$, \\ Pandiyan Indira Gandhi ${ }^{4}$, Nellaiappan Olaganathan Gopal ${ }^{2}$ \\ ${ }^{1}$ Department of Food Science, Tamil Nadu Agricultural University, Tamil Nadu, India. \\ ${ }^{2}$ Department of Agricultural Microbiology, Tamil Nadu Agricultural University, Tamil Nadu, India. \\ ${ }^{3}$ Korean Agricultural Culture Collection, National Academy of Agricultural Science, \\ Republic of Korea. \\ ${ }^{4}$ Regional Research Station, Tamil Nadu Agricultural University, Tamil Nadu, India.
}

Submitted: May 14, 2014; Approved: February 16, 2015.

\begin{abstract}
Adhirasam is a cereal based, doughnut shaped, deep fried dessert consumed in the southern regions of India. The dough used to prepare adhirasam is fermented and contains rice flour and jaggery. The aim of the present study was to characterize the cultivable bacteria associated with this fermented dough and to identify a suitable starter culture for the production of quality adhirasam. In total, one hundred and seventy bacterial isolates were recovered from de Man Rogosa Sharp (MRS) agar, nutrient agar, lysogeny agar and tryptic soy agar media. Out of the 170 bacterial isolates, sixteen isolates were selected based on their ability to tolerate glucose and sucrose. All the bacterial isolates tolerated $15 \%$ glucose and $30 \%$ sucrose. Analyses of $16 \mathrm{~S}$ rDNA gene sequences of the bacterial isolates showed that the dominant cultivable bacteria were members of the genus Bacillus. These strains were further used as starters and tested for their ability to ferment rice flour with jaggery to produce adhirasam dough. Organoleptic evaluation was carried out to choose the best starter strain. Adhirasam prepared from Bacillus subtilis isolates S4-P11, S2-G2-A1 and S1-G15, Bacillus tequilensis isolates S2-H16, S3-P9, S3-G10 and Bacillus siamensis isolate S2-G13 were highly acceptable to consumers. Adhirasam prepared using these starter cultures had superior product characteristics such as softness in texture, flavor and enhanced aroma and sweet taste.
\end{abstract}

Key words: Adhirasam, fermented cereal product, Bacillus, South Indian dessert.

\section{Introduction}

Cereals are staple foods for billions of people across the globe, especially in the Indian sub-continent, Asia and Africa. Cereals are important substrates in fermented foods and it is reported that fermented foods comprise one third of the diets in the world (Marshall and Mejia, 2011). Several fermented cereal products have been documented including sourdough from America, Australia, and Europe (Brandt, 2007), Idli and dosa from India (Soni et al., 1985; 1991; Agaliya and Jeevaratnam, 2013), and Puto from South East Asia (Kelly et al., 1995). The presence of obligate heterofermentative lactic acid bacteria (Leuconostoc mesenteroides) and yeast species (Saccharomyces cerevisiae, Debaryomyces hansenii, Pichia anomala and Trichosporon pullulans) has been documented during the fermentation of idli batter (Aidoo et al., 2006). Park et al. (2010) have reported that Bacillus amyloliquefaciens, B. subtilis, and Bacillus vallismortis were dominant in the traditionally fermented Korean soybean paste, eoyukjang. Hong et al. (2012) have documented an increase in the aroma characteristics of the fermented Korean soybean paste, Doenjang, upon inoculation with $B$. amyloliquefaciens. Previously, Lee et al. (2013) have isolated the probiotic, B. subtilis KU201 from kimchi, which has antifungal and antimicrobial properties. Choi et al.

Send correspondence to R. Anandham. Department of Agricultural Microbiology, Agricultural College and Research Institute, Tamil Nadu Agricultural University, Madurai 625 104, Tamil Nadu, India. E-mail: anandhamranga@gmail.com. 
(2010) have developed a fermented soymilk product with Bacillus subtilis as the starter culture and have found that this fermented soymilk exhibited high antioxidant activity. Cheonggukjang, produced with the co-inoculation of the probiotics B. subtilis $\mathrm{W} 42$ and B. amyloliquefaciens MJ1-4, exhibited high antioxidant and fibrinolytic activities (Cho et al., 2014).

Adhirasam is an ethnic fermented cereal-based food of South India, especially Tamil Nadu state. It is a doughnut-shaped, spongy, deep fried food that is consumed during festivals and special occasions. People may also occasionally consume the adhirasam dough without deep frying. To the best of our knowledge, there is no literature describing the microbiology of the fermented adhirasam dough. Therefore, this study was formulated to investigate the cultivable bacteria involved in the fermentation of adhirasam dough and to identify a promising starter culture.

\section{Materials and Methods}

\section{Sample collection and isolation of microorganisms}

Thirty samples of 3-day fermented adhirasam dough were collected from adhirasam producers in Madurai district, Tamil Nadu state, India. The samples were packed in polyethylene pouches and stored in the refrigerator at $4{ }^{\circ} \mathrm{C}$ for subsequent analysis. Ten grams of adhirasam dough from each sample was aseptically transferred into a $250 \mathrm{~mL}$ flask containing $90 \mathrm{~mL}$ sterile saline solution $(0.85 \mathrm{~g} / \mathrm{L}$ $\mathrm{NaCl}$ ) and the contents were mixed thoroughly for $30 \mathrm{~min}$ at $150 \mathrm{rpm}$. Serial dilutions $\left(10^{-1}\right.$ to $\left.10^{-8}\right)$ were made for each sample, and $100 \mu \mathrm{L}$ of the each dilution was spread onto each de Man Rogosa Sharpe agar (MRSA), Nutrient agar (NA), Lysogeny agar (LA), trypticase soy agar media (TSA) (Himedia, India). After two days of incubation at $30^{\circ} \mathrm{C}$, bacterial colonies were isolated and purified. Fungi (yeasts and molds) were enumerated on Rose Bengal choramphenicol agar (Himedia, India) as described previously (Zheng et al., 2013).

\section{Identification of bacterial isolates}

Cell morphology, Gram staining, catalase and oxidase activity, curdling, spore formation, sugar fermentation (glucose, sucrose and lactose) and glucose and sucrose tolerance tests were performed to characterize the isolates (Gerhardt et al., 1994). Glucose tolerance was tested in a nutrient broth with $5 \%, 10 \%, 15 \%$ or $20 \%$ glucose after 2 days of fermentation at $30^{\circ} \mathrm{C}$. Sucrose tolerance of bacteria was tested in nutrient broth (devoid of glucose) having sucrose concentrations ranging from $10 \%$ to $80 \%$ with 10 unit increments, by incubation for 2 days at $30{ }^{\circ} \mathrm{C}$. Curdling activity was tested in toned milk medium prepared from bacteria free toned milk (Terzic-Vidojevic et al., 2009). The hemolytic property of Bacillus spp. isolated from adhirasam dough was determined according to
Benson (2002). Molecular characterization was performed according to Kim et al. (2011). Briefly, the gene encoding bacterial 16S rRNA was amplified through Polymerase Chain Reaction (PCR) with forward primer 27F: 5'-AGAGTTTGATCCTGGCTCAG-3' and reverse primer 1492R: 5'-GGTTACCTTGTTACGACTT-3'. The 16S rRNA nucleotide sequences were obtained by PCR direct sequencing using the fluorescent dye terminator method (ABI Prism ${ }^{\mathrm{TM}}$ Bigdye $^{\mathrm{TM}}$ Terminator cycle sequencing ready reaction kit v.3.1) and the products were purified using the Millipore-Montage dye removal kit. Finally, the products were run in an ABI3730XL capillary DNA sequencer (50 $\mathrm{cm}$ capillary). Nearly complete $16 \mathrm{~S}$ rRNA gene sequences from the automatic sequencer were aligned and bacterial identities were deduced from the EzTaxon-e server (http://eztaxon-e.ezbiocloud.net/) to ascertain their closest relatives. The sequences obtained from this study were submitted to NCBI with accession numbers KC851825 to KC851840.

\section{Determination of antimicrobial activity}

To examine the antimicrobial activity, 14 Bacillus spp. isolated from adhirasam dough were used. Bacillus spp. isolates were grown in $100 \mathrm{~mL}$ of nutrient broth (Himedia, India) at $30{ }^{\circ} \mathrm{C}$, and $120 \mathrm{rpm}$ for $24 \mathrm{~h}$. The antimicrobial activity was investigated against human pathogens viz., Escherichia coli MTCC 2622, Staphylococcus aureus MTCC 1144, Listeria monocytogens MTCC 1143, Saccharomyces cerevisiae MTCC 36 and Bacillus cereus MTCC 1272 as described previously (Zheng et al., 2013). These pathogenic bacteria were obtained from the Microbial Type Culture Collection (MTCC), Chandigarh, India.

\section{Preparation of adhirasam dough, inoculation with starter cultures and estimation of population dynamics}

Bacillus spp. isolates were grown in $25 \mathrm{~mL}$ of nutrient broth, in an incubator shaker at $120 \mathrm{rpm}$ for 2 days at $30^{\circ} \mathrm{C}$. The bacterial cells were harvested by centrifugation at $8,000 \mathrm{~g}$ at $4{ }^{\circ} \mathrm{C}$ for $15 \mathrm{~min}$. The bacterial cells were washed 2-3 times with $0.85 \% \mathrm{NaCl}$ and resuspended in physiological saline.

Rice (Oryza sativa L.), local variety 'IR20', and jaggery were purchased from the local market. Adhirasam dough was prepared in the laboratory following the traditional method. One kilogram of rice was sorted, washed and soaked at ambient temperature $\left(28-30^{\circ} \mathrm{C}\right)$ for $1 \mathrm{~h}$. Water was decanted, and the soaked rice was pounded and sieved to get rice flour. Jaggery syrup was prepared separately by mixing $750 \mathrm{~g}$ of jaggery in $300 \mathrm{~mL}$ distilled water and heating to $80{ }^{\circ} \mathrm{C}$ to get desired consistency. Immediately, one kilogram of rice flour was mixed with this $300 \mathrm{~mL}$ of hot jaggery syrup and kneaded into soft dough under aseptic conditions. After the dough reached room 
temperature, equal quantities (100 g) of dough were distributed in $500 \mathrm{~mL}$ bottles and sterilized. The dough was then inoculated with $1 \%$ saline suspended bacterial inoculum $\left(\sim 1 \times 10^{6} \mathrm{cfu} / \mathrm{mL}\right)$ and incubated at $30{ }^{\circ} \mathrm{C}$ for 3 days. For controls, the dough was not sterilized and inoculated with $1 \mathrm{~mL}$ of $0.85 \% \mathrm{NaCl}$ instead of the bacterial inoculum and incubated at $30{ }^{\circ} \mathrm{C}$ for 3 days. This experiment was conducted three times and the replicates were arranged in a completely randomized block design.

The dough $(10 \mathrm{~g})$ was withdrawn from each treatment on day 1,2 , and 3 . Bacterial survivability and the changes in the inoculated bacterial population in the dough were evaluated in NA after 2 days of incubation at $30^{\circ} \mathrm{C}$. Simultaneously, the $\mathrm{pH}$ of the dough was measured after mixing with distilled water (1:5, solid: water). This mixture was allowed to stand for $15 \mathrm{~min}$ with intermittent stirring before readings were taken.

\section{Sensory evaluation of dough and the adhirasam prepared using different starter culture}

Fermented dough, both naturally fermented and fermented with the starter culture, was organoleptically evaluated for color, aroma, perforations and texture by a panel of 10 trained judges using a 9 point hedonic scale as described by Larmond (1977). The judges were provided with a prescribed format to record their observations. The following are the scores of the hedonic scale used: $9=$ Like extremely; $8=$ Like very much; $7=$ Like moderately; $6=$ Like slightly; $5=$ Neither like nor dislike; $4=$ Dislike slightly; $3=$ Dislike moderately; 2 = Dislike very much; 1 = Dislike extremely. The panelists were asked to expectorate the dough and rinse their mouth using distilled water between samples. Sensory testing was made in a panel room that was completely free of food/chemical odor, unnecessary sound and mixing of daylight.

All the fermented dough samples, both naturally fermented (control) and starter culture fermented, were portioned, flattened and made in to doughnut shapes and deep fried in hot edible oil until golden brown in color. The color, flavor, texture, taste and overall acceptability of the prepared product was also organoleptically evaluated by a panel of 10 trained judges using the 9 point hedonic scale as described above.

\section{Statistical analysis}

The data were analyzed using analysis of variance (ANOVA) with general linear model (ver 9.1; SAS institute Inc, Cary, NC, USA). Means were compared using least significant difference (LSD). The significance levels were within confidence limits of 0.05 or less.

\section{Results and Discussion}

\section{Characterization of bacteria isolated from adhirasam dough}

Fermentation with a starter culture generally reduces fermentation time, imparts volatility during fermentation and improves product characteristics such as flavor, color, texture and taste. Fermented products have both longer shelf life and better value. In the present study, 170 bacterial isolates were obtained from thirty different adhirasam dough samples; of these, 40, 52, 40 and 38 bacterial isolates were recovered from MRSA, NA, LA and TSA media, respectively. From the 170 isolates, only 64 were selected for further biochemical characterization based on colony size, color, and morphology. Morphologically $97 \%$ of bacterial isolates were Gram positive, spore forming rods, while $75 \%$ were oxidase positive and $87.5 \%$ were catalase positive. In the curdling test, $42.2 \%$ of the isolates produced thick curd with a pleasant curd smell while $40.6 \%$ of the isolates produced curd after $24-36 \mathrm{~h}$ of incubation. All isolates were able to ferment glucose and $16 \%$ of the isolates produced gas. Seventy-five percent of the isolates fermented sucrose and $14 \%$ produced gas. Thirty percent of the isolates fermented lactose and $13 \%$ produced gas. All isolates were able to grow in $15 \%$ of glucose, and $96 \%$ of the isolates could tolerate $20 \%$ glucose. All the isolates were able to grow in $30 \%$ sucrose, $22 \%$ of the isolates grew in $70 \%$ sucrose. Yeast and molds were not recovered from any of the samples tested. Traditionally, jaggery is prepared by the concentration of a sugarcane juice extract, made from locally cultivated sugarcane, without the use of any chemicals. Jaggery is the major ingredient in the adhirasam dough, and can constitute up to $75 \%$ of the product. Sucrose is one of the major sugars present in jaggery, and its concentration ranges between 66-77\% (Chand et al., 2012). Hence, the 16 bacterial isolates that could tolerate $70 \%$ sucrose were alone selected for molecular characterization and further studies.

A summary of the morphological and biochemical characteristics of the selected bacterial isolates is presented in Table 1. The results of the $16 \mathrm{~S}$ rDNA gene sequence analysis revealed that 14 of the 16 isolates belonged to the Bacillus spp. and the remaining 2 isolates were identified as Enterobacter mori (Table 2). The Food and Drug Administration (FDA) recognizes some substances derived from $B$. subtilis as GRAS, and this species is also used as a probiotic. Fermented soybean, natto, which is commonly consumed in Japan, contains $10^{8}$ viable B. subtilis per gram of food; it also has anti-cancer properties and can stimulate the immune system (Hosoi and Kiuchi, 2004). Sarkar et al. (1994) isolated B. subtilis as the functional bacterium from kinema, a fermented soybean food. Out of the 16 isolates, $80 \%$ of them were able to produce curd from bacteria-free milk. Our results are similar to previous reports of Bacillus spp. causing sweet curdling of milk due to the production of 


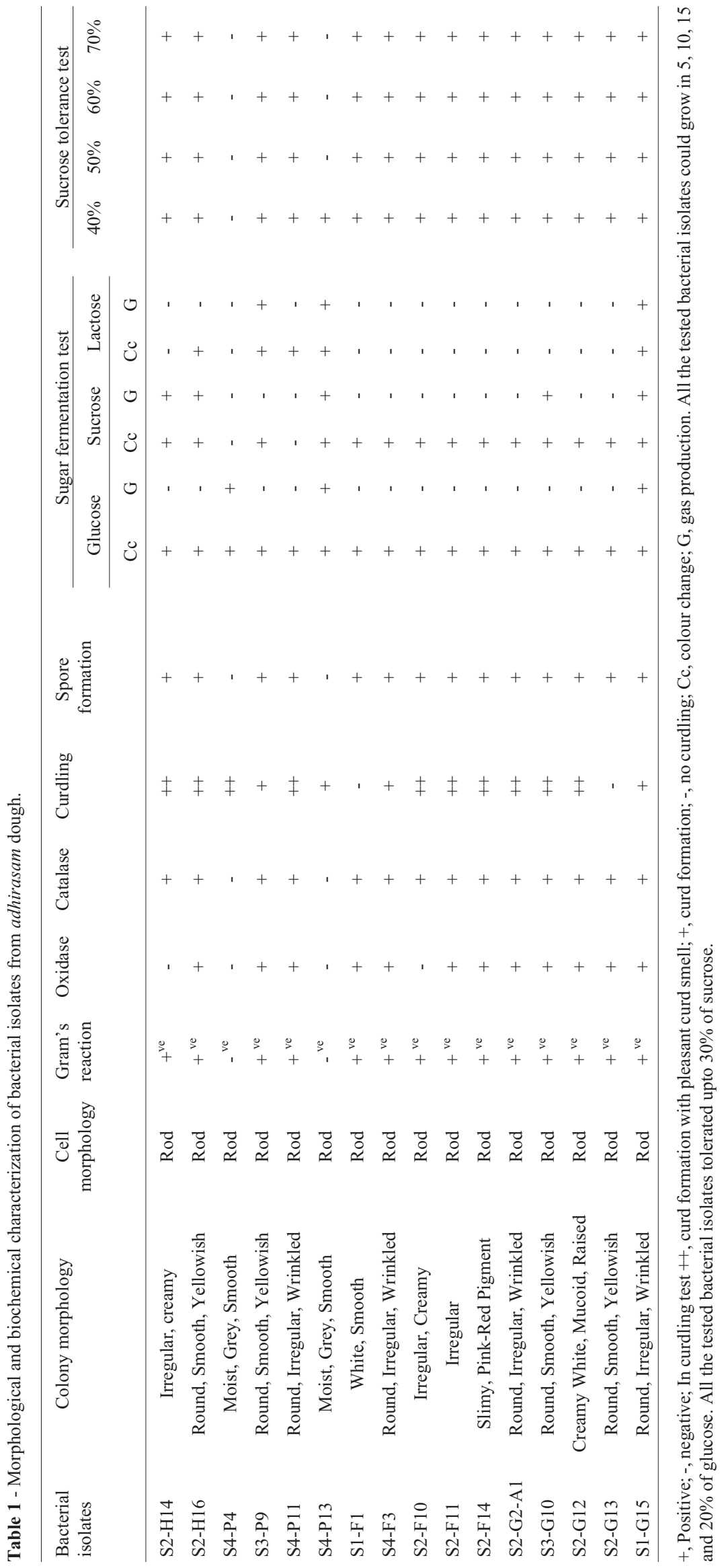


Table 2 - Molecular characterization of bacterial isolates obtained from adhirasam dough.

\begin{tabular}{|c|c|c|c|c|c|}
\hline S. No. & Bacterial isolates & Closest relative & Identity match (\%) & NCBI accession number & Sequenced length (bp) \\
\hline 1 & S2-H14 & Bacillus subtilis subsp. spizizenii & 99.86 & KC851825 & 1481 \\
\hline 2 & S2-H16 & Bacillus tequilensis & 99.93 & KC851826 & 1486 \\
\hline 3 & S4-P4 & Enterobacter mori & 99.32 & KC851827 & 1474 \\
\hline 4 & S3-P9 & Bacillus tequilensis & 99.93 & KC851828 & 1489 \\
\hline 5 & S4-P11 & Bacillus subtilis subsp. subtilis & 99.93 & KC851829 & 1481 \\
\hline 6 & S4-P13 & Enterobacter mori & 99.46 & KC851830 & 1473 \\
\hline 7 & S1-F1 & Bacillus safensis & 100 & KC851831 & 1481 \\
\hline 8 & S4-F3 & Bacillus subtilis subsp. inaquosorum & 99.83 & KC851832 & 1478 \\
\hline 9 & S2-F10 & Bacillus subtilis subsp. spizizenii & 99.86 & KC851833 & 1475 \\
\hline 10 & S2-F11 & Bacillus aerophilus & 100 & $\mathrm{KC} 851834$ & 1487 \\
\hline 11 & S2-F14 & Bacillus endophyticus & 99.66 & KC851835 & 1481 \\
\hline 12 & S2-G2-A1 & Bacillus subtilis subsp. subtilis & 99.93 & KC851836 & 1477 \\
\hline 13 & S3-G10 & Bacillus tequilensis & 99.93 & KC851837 & 1487 \\
\hline 14 & S2-G12 & Bacillus siamensis & 99.93 & KC851838 & 1480 \\
\hline 15 & S2-G13 & Bacillus tequilensis & 99.93 & KC851839 & 1480 \\
\hline 16 & S1-G15 & Bacillus subtilis subsp. subtilis & 99.93 & KC851840 & 1481 \\
\hline
\end{tabular}

enzymes proteinase, lipase and phospholipase (Sarkar et al., 1994; Meer et al., 1991). As none of the Bacillus spp. isolated from this study exhibited any hemolytic activity, they were used for developing starter inocula. The E. mori isolates were reported to be plant pathogens and hence were not used for further testing. Bacillus spp. isolates S2-H14, S4-P11, S4-F3, S2-F10, S2-G2-A1 and S1-G15 inhibited the growth of E. coli MTCC 262 and S. aureus MTCC 1144. However, none of the Bacillus isolates inhibited the growth of L. monocytogens MTCC 1143, S. cerevisiae MTCC 36 and B. cereus MTCC 1272 (Table 3).

\section{Sensory properties of fermented adhirasam dough}

On the first day of fermentation, the dough was found to be compact, firm and without perforations. However, on the third day of fermentation, the dough lost some of its texture, and perforations were seen on the surface of the dough (Figure 1). Dough fermented with B. subtilis isolates S1G15, S2-G2-A1, S4-P11 and with the B. safensis S2-G12 isolate exhibited greater perforation compared to other isolates, and hence were given maximum scores. The aroma of the dough fermented with these bacterial isolates was also superior to control. Individual inoculation of $B$. safensis S2-G12, B. subtilis subsp. subtilis S1-G15, S2-G2-A1, S4$\mathrm{P} 11$ and B. tequilensis isolates S3-G10, S2-G13, S3-P9, S2-H16 were also scored maximum for aroma enhancement during fermentation. A previous study has documented the aroma producing properties of B. subtilis; specifically, acetoin produced leads to a pleasant and buttery odor, and metabolic engineering has further improved its prospective production (Chen et al., 2013). Thus it is possible that the observed aroma enhancement during fermentation was due to the acetoin produced by the isolates. There was not much difference in color among dough fermented with the various isolates, but were all better than control. The texture of the dough improved as fermentation progressed and dough with more perforations attained better texture. The texture scores of all the treatments were higher compared to control, and the overall acceptability improved due to inoculation with the various isolates as starter cultures (Table 4).

B. subtilis is also associated with many other fermented products like meju, a Japanese traditional soybean food, thua-nao, a Northern Thailand fermented soybeans, fermented soybeans of North East India such as kinema, hawaijar, tungrymbai, tungtoh, aakhonelaxone, bekang, peruyaan, bemerthu, and maseura, a black gram fermented food of North East India (Tamang et al., 1999, 2012; Chantawannakul et al., 2002; Terzic-Vidojevic et al., 2009; Kim et al., 2011). Similarly, the Bacillus spp. also dominate

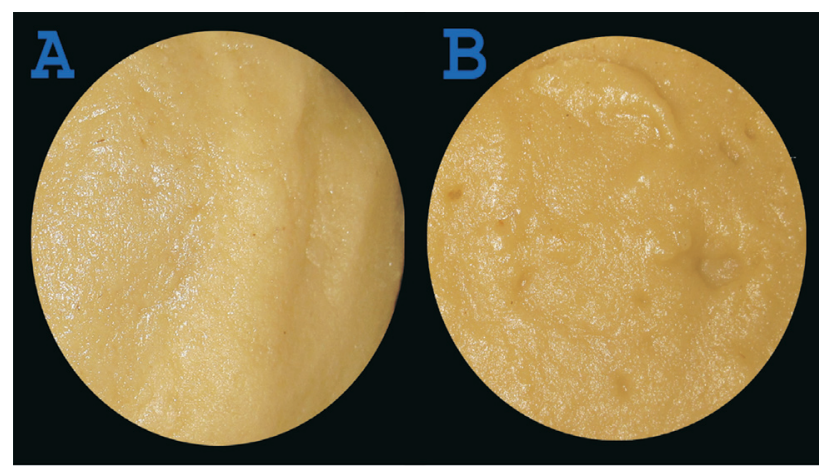

Figure 1 - Perforations in adhirasam dough after three days of fermentation; Uninoculated control (a); Dough fermented with inoculation of $B$. subtilis subsp. subtilis S1-G15 (b). 
in Daqu- a traditional fermentation starter used to produce flavored vinegar and Chinese liquor (Zheng et al., 2013). During the preparation of adhirasam, jaggery syrup temperature was raised to $80^{\circ} \mathrm{C}$. Such temperature should have a selective effect on the microbiota, favoring the thermotolerant, and aerobic endospore forming bacteria.
As the Bacillus spp. possess all these characteristics, they can persist and outcompete the fungi and yeast. The antimicrobial activity of Bacillus may be another reason why Bacillus spp. become dominant in the adhirasam dough. The principle requirements of starter culture strains are rapid production of $\mathrm{CO}_{2}$ from sugars and the generation

Table 3 - Antimicrobial activity of cell free supernatants of Bacillus spp.

\begin{tabular}{|c|c|c|c|c|c|}
\hline \multirow[t]{2}{*}{ Antagonistic bacteria } & \multicolumn{5}{|c|}{ Pathogens } \\
\hline & $\begin{array}{l}\text { Escherchia coli } \\
\text { MTCC } 2622\end{array}$ & $\begin{array}{c}\text { Listeria monocytogens } \\
\text { MTCC } 1143\end{array}$ & $\begin{array}{c}\text { Saccharomyces } \\
\text { cerevisiae MTCC } 36\end{array}$ & $\begin{array}{c}\text { Bacillus cereus } \\
\text { MTCC } 1272\end{array}$ & $\begin{array}{c}\text { Staphylococcus } \\
\text { aureus MTCC } 1144\end{array}$ \\
\hline Bacillus subtilis subsp. spizizenii S2-H14 & ++ & - & - & - & + \\
\hline Bacillus tequilensis S2-H16 & - & - & - & - & - \\
\hline Bacillus tequilensis S3-P9 & - & - & - & - & - \\
\hline Bacillus subtilis subsp. subtilis S4-P11 & ++ & - & - & - & + \\
\hline Bacillus safensis $\mathrm{S} 1-\mathrm{F} 1$ & ++ & - & - & - & + \\
\hline Bacillus subtilis subsp. inaquosorum $\mathrm{S} 4-\mathrm{F} 3$ & ++ & - & - & - & + \\
\hline Bacillus subtilis subsp. Spizizenii S2-F10 & ++ & - & - & - & + \\
\hline Bacillus aerophilus S2-F11 & - & - & - & - & - \\
\hline Bacillus endophyticus S2-F14 & - & - & - & - & - \\
\hline Bacillus tequilensis S3-G10 & - & - & - & - & - \\
\hline Bacillus siamensis $\mathrm{S} 2-\mathrm{G} 12$ & - & - & - & - & - \\
\hline Bacillus siamensis $\mathrm{S} 2-\mathrm{G} 13$ & - & - & - & - & - \\
\hline Bacillus subtilis subsp. subtilis $\mathrm{S} 1-\mathrm{G} 15$ & ++ & - & - & - & + \\
\hline
\end{tabular}

-, Not detectable; ++ diameter of inhibition zone between $10-15 \mathrm{~mm}$; +, diameter of inhibition zone less than $5 \mathrm{~mm}$.

Table 4 - Organoleptic evaluation of adhirasam dough fermented with different bacterial isolates.

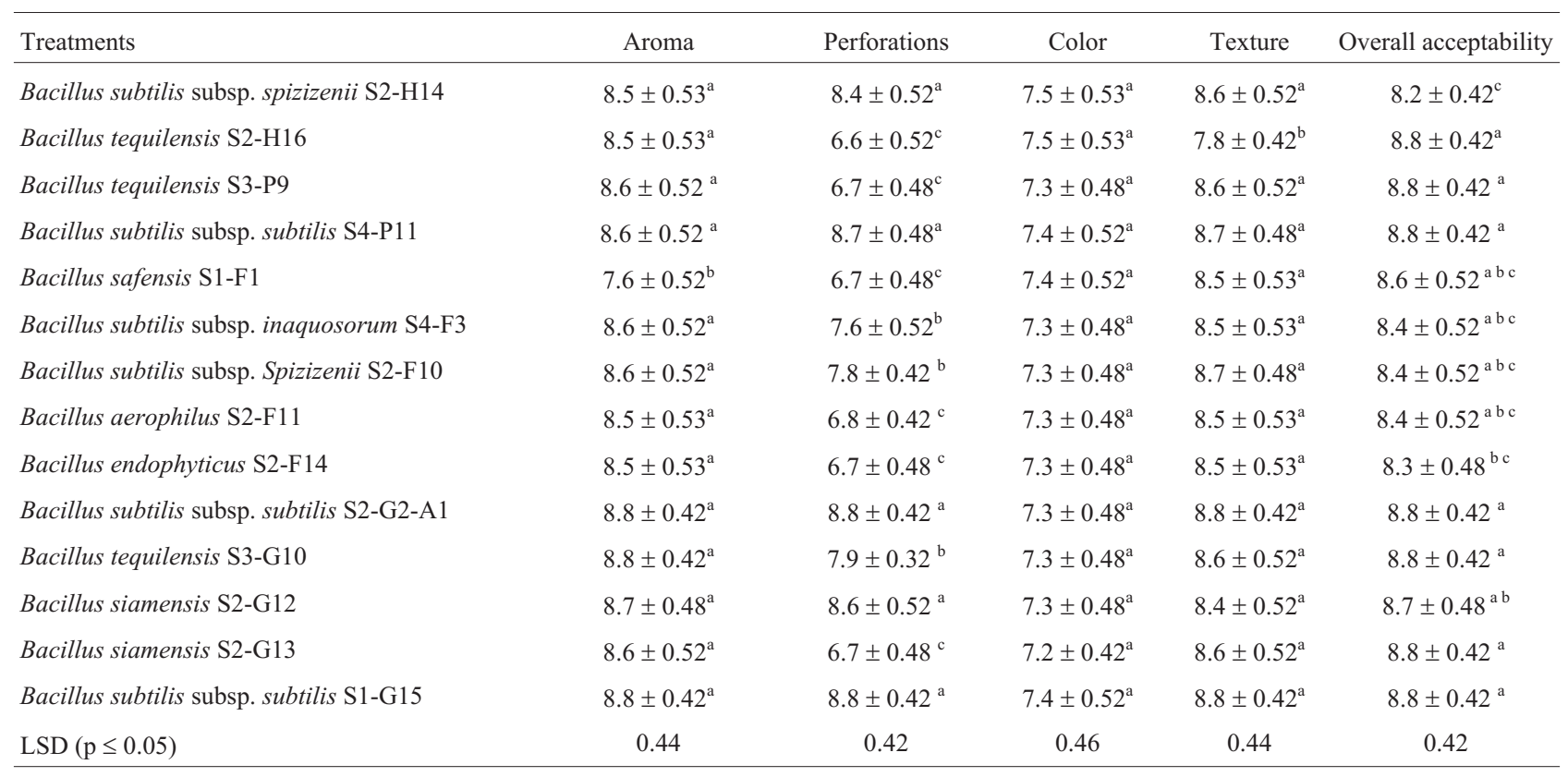

Data represents the mean scores ( \pm Standard deviations) of ten judges. Values bearing different superscripts in each column differ significantly $(\mathrm{p}<0.05)$. Naturally fermented dough was used as control (7 Like moderately), score 1, dislike extremely; score 2, dislike very much; score 3, dislike moderately; score 4, dislike slightly; score 5, neither like nor dislike; score 6, like slightly; score 8, like very much; score 9, like extremely. 

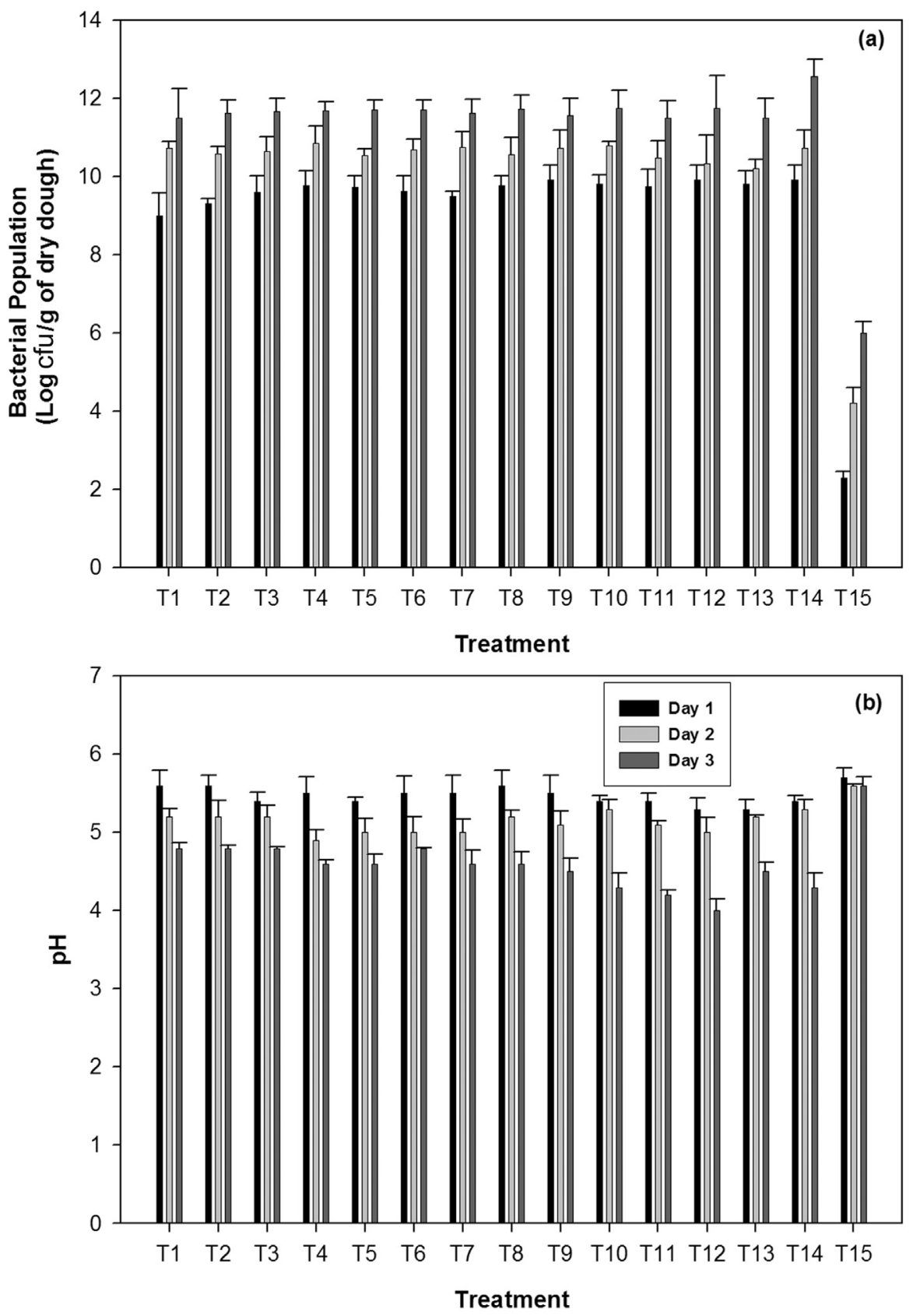

Figure 2 - Changes in bacterial population (a) and $\mathrm{pH}$ (b) during fermentation of adhirasam dough. Initial $\mathrm{pH}$ of dough was 6.0. The treatment details were as follows; T1- B. subtilis subsp. spizizenii S2-H14; T2-B. tequilensis $\mathrm{S} 2-\mathrm{H} 16$; T3-B. tequilensis $\mathrm{S} 3-\mathrm{P} 9$; T4- B. subtilis subsp. subtilis S4-P11; T5Bacillus safensis S1-F1; T6- B. subtilis subsp. inaquosorum S4-F3; T7-B. subtilis subsp. spizizenii S2-F10; T8- Bacillus aerophilus S2-F11; T9- Bacillus endophyticus S2-F14; T10- B. subtilis subsp. subtilis S2-G2-A1; T11- B. tequilensis S3-G10; T12- B. siamensis S2-G12; T13-B. tequilensis S2-G13; T14- B. subtilis subsp. subtilis S1-G15; T15- Control.

of good bread flavor (Decock and Cappelle, 2005). In the present study, the inoculated Bacillus spp. probably produced thermostable enzymes that degraded cell walls and other polysaccharides that might be implicated in the development of flavor precursors such as pyrazines (Zheng et al., 2013). Yonzan and Tamang (2013) have tested lactic acid bacteria and yeast for their ability to ferment rice flour for making selroti, and have also evaluated its organoleptic properties using a 5 point hedonic scale.

\section{Population changes in bacterial species during fermentation}

The dynamics of the viable bacterial counts during adhirasam fermentation are presented in Figure 2a. Among the different treatments, the lowest total bacterial 
count was registered in controls (2 log cfu / g of dry dough) on day 1 . As incubation progressed the total number of bacteria also increased. A maximum population of $12 \log \mathrm{cfu} / \mathrm{g}$ of dry dough was observed in dough inoculated with B. subtilis subsp. subtilis S1-G15. On day 3 of fermentation, dough inoculated with Bacillus siamensis S2-G12 reduced dough $\mathrm{pH}$ from 6.0 to 4.0 (Figure 2b). In a previous study, Zheng et al. (2013) have reported that Bacillus spp. were continuously present throughout the fermentation of Daqu. Thus it is possible that the Bacillus spp. also similarly persisted throughout the fermentation of the adhirasam dough.

\section{Sensory properties of adhirasam prepared from fermented dough}

Adhirasam prepared from inoculum fermented dough had better appearance, color, flavor, texture and taste compared to that prepared using control dough. The appearance and color of the product were all equally acceptable, irrespective of the treatment. The flavor and texture of adhirasam prepared from various treatments were enhanced due to fermentation (Figure 3). It is generally known that a soft texture and sweet taste with golden brown color of the fried adhirasam is considered to be the best by the consumers. The adhirasam prepared from dough fermented with B. subtilis isolates S2-G2-A1, S4-P11, S1-

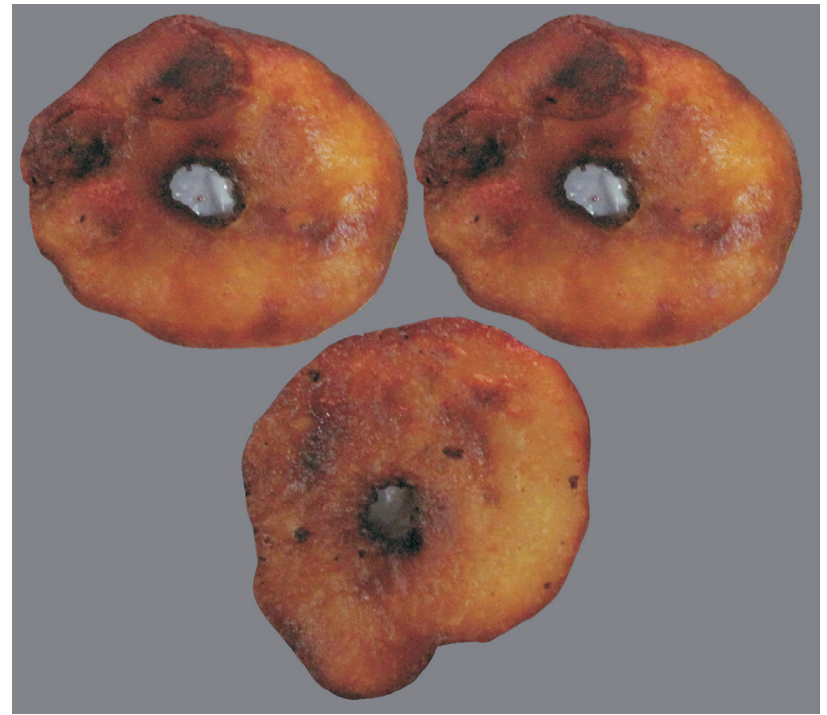

Figure 3 - Adhirasam product prepared from dough fermented with $B$. subtilis subsp. subtilis S1-G15.

G15 showed superior flavor and texture retention even after frying in hot edible oil, and were followed by adhirasam prepared from dough fermented by $B$. tequilensis isolates S3-G10, S2-G13, S3-P9 and S2-H16. The taste of adhirasam prepared using dough fermented with bacterial starter culture(s) was significantly better compared to control (Table 5).

Table 5 - Organoleptic evaluation of adhirasam prepared from fermented dough.

\begin{tabular}{|c|c|c|c|c|c|c|}
\hline Treatment & Appearance & Color & Flavor & Texture & Taste & Overall acceptability \\
\hline Bacillus subtilis subsp. spizizenii $\mathrm{S} 2-\mathrm{H} 14$ & $8.1 \pm 0.32^{\mathrm{e}}$ & $8.2 \pm 0.42^{\mathrm{d}}$ & $8.2 \pm 0.42^{\mathrm{c}}$ & $8.2 \pm 0.42^{c}$ & $8.2 \pm 0.42^{\mathrm{d}}$ & $8.2 \pm 0.42^{\mathrm{c}}$ \\
\hline Bacillus tequilensis S2-H16 & $8.8 \pm 0.42^{\mathrm{ab}}$ & $8.8 \pm 0.42^{\mathrm{ab}}$ & $8.8 \pm 0.42^{\mathrm{ab}}$ & $8.8 \pm 0.42^{\mathrm{ab}}$ & $8.8 \pm 0.42^{\mathrm{ab}}$ & $8.8 \pm 0.42^{\mathrm{ab}}$ \\
\hline Bacillus tequilensis $\mathrm{S} 3-\mathrm{P} 9$ & $8.8 \pm 0.42^{\mathrm{ab}}$ & $8.8 \pm 0.42^{\mathrm{ab}}$ & $8.8 \pm 0.42^{\mathrm{ab}}$ & $8.8 \pm 0.42^{\mathrm{ab}}$ & $8.8 \pm 0.42^{\mathrm{ab}}$ & $8.8 \pm 0.42^{\mathrm{ab}}$ \\
\hline Bacillus subtilis subsp. subtilis $\mathrm{S} 4-\mathrm{P} 11$ & $8.9 \pm 0.32^{\mathrm{a}}$ & $8.9 \pm 0.32^{\mathrm{a}}$ & $8.9 \pm 0.32^{\mathrm{a}}$ & $8.9 \pm 0.32^{\mathrm{a}}$ & $8.9 \pm 0.32^{\mathrm{a}}$ & $8.9 \pm 0.32^{\mathrm{a}}$ \\
\hline Bacillus safensis S1-F1 & $8.1 \pm 0.32^{\mathrm{e}}$ & $8.2 \pm 0.42^{\mathrm{d}}$ & $8.2 \pm 0.42^{\mathrm{c}}$ & $8.2 \pm 0.42^{\mathrm{c}}$ & $8.2 \pm 0.42^{\mathrm{d}}$ & $8.2 \pm 0.42^{\mathrm{c}}$ \\
\hline $\begin{array}{l}\text { Bacillus subtilis subsp. inaquosorum } \\
\text { S4-F3 }\end{array}$ & $8.4 \pm 0.52^{\text {cde }}$ & $8.4 \pm 0.52^{\mathrm{cd}}$ & $8.5 \pm 0.53^{\mathrm{bc}}$ & $8.4 \pm 0.52^{\mathrm{c}}$ & $8.7 \pm 0.48^{\mathrm{abc}}$ & $8.6 \pm 0.52^{\mathrm{ab}}$ \\
\hline Bacillus subtilis subsp. spizizenii $\mathrm{S} 2-\mathrm{F} 10$ & $8.2 \pm 0.42^{\mathrm{de}}$ & $8.2 \pm 0.42^{\mathrm{d}}$ & $8.2 \pm 0.42^{\mathrm{c}}$ & $8.2 \pm 0.42^{\mathrm{c}}$ & $8.2 \pm 0.42^{\mathrm{d}}$ & $8.2 \pm 0.42^{\mathrm{c}}$ \\
\hline Bacillus aerophilus S2-F11 & $8.6 \pm 0.52^{\mathrm{abc}}$ & $8.6 \pm 0.52^{\mathrm{abc}}$ & $8.3 \pm 0.48^{\mathrm{c}}$ & $8.5 \pm 0.53^{\mathrm{bc}}$ & $8.4 \pm 0.52^{\mathrm{cd}}$ & $8.5 \pm 0.53^{\mathrm{bc}}$ \\
\hline Bacillus endophyticus S2-F14 & $8.4 \pm 0.52^{\text {cde }}$ & $8.5 \pm 0.53^{\mathrm{bcd}}$ & $8.7 \pm 0.48^{\mathrm{ab}}$ & $8.4 \pm 0.52^{\mathrm{c}}$ & $8.5 \pm 0.53^{\mathrm{bcd}}$ & $8.5 \pm 0.53^{\mathrm{bc}}$ \\
\hline $\begin{array}{l}\text { Bacillus subtilis subsp. subtilis } \\
\text { S2-G2-A1 }\end{array}$ & $8.9 \pm 0.32^{\mathrm{a}}$ & $8.9 \pm 0.32^{\mathrm{a}}$ & $8.9 \pm 0.32^{\mathrm{a}}$ & $8.9 \pm 0.32^{\mathrm{a}}$ & $8.9 \pm 0.32^{\mathrm{a}}$ & $8.9 \pm 0.32^{\mathrm{a}}$ \\
\hline Bacillus tequilensis S3-G10 & $8.8 \pm 0.42^{\mathrm{ab}}$ & $8.8 \pm 0.42^{\mathrm{ab}}$ & $8.8 \pm 0.42^{\mathrm{ab}}$ & $8.8 \pm 0.42^{\mathrm{ab}}$ & $8.8 \pm 0.42^{\mathrm{ab}}$ & $8.8 \pm 0.42^{\mathrm{ab}}$ \\
\hline Bacillus siamensis $\mathrm{S} 2-\mathrm{G} 12$ & $8.5 \pm 0.53^{\mathrm{bcd}}$ & $8.5 \pm 0.53^{\mathrm{bcd}}$ & $8.5 \pm 0.53^{\mathrm{bc}}$ & $8.5 \pm 0.53^{\mathrm{bc}}$ & $8.5 \pm 0.53^{\mathrm{bcd}}$ & $8.5 \pm 0.53^{\mathrm{bc}}$ \\
\hline Bacillus siamensis $\mathrm{S} 2-\mathrm{G} 13$ & $8.8 \pm 0.42^{\mathrm{ab}}$ & $8.8 \pm 0.42^{\mathrm{ab}}$ & $8.8 \pm 0.42^{\mathrm{ab}}$ & $8.8 \pm 0.42^{\mathrm{ab}}$ & $8.8 \pm 0.42^{\mathrm{ab}}$ & $8.8 \pm 0.42^{\mathrm{ab}}$ \\
\hline Bacillus subtilis subsp. subtilis $\mathrm{S} 1-\mathrm{G} 15$ & $8.9 \pm 0.32^{\mathrm{a}}$ & $8.9 \pm 0.32^{\text {a }}$ & $8.9 \pm 0.32^{\mathrm{a}}$ & $8.9 \pm 0.32^{\mathrm{a}}$ & $8.9 \pm 0.32^{\text {a }}$ & $8.9 \pm 0.32^{\mathrm{a}}$ \\
\hline $\operatorname{LSD}(p \leq 0.05)$ & 0.38 & 0.39 & 0.38 & 0.39 & 0.39 & 0.39 \\
\hline
\end{tabular}

Data represents the mean scores ( \pm standard deviations) of ten judges. Values bearing different superscripts in each column differ significantly ( $p<0.05$ ). Naturally fermented dough was used as control (7 Like moderately), score 1, dislike extremely; score 2, dislike very much; score 3, dislike moderately; score 4, dislike slightly; score 5, neither like nor dislike; score 6, like slightly; score 8 , like very much; score 9, like extremely. 


\section{Conclusion}

In conclusion, the Bacillus spp. were the dominant and active species in adhirasam dough and imparted both structure and flavor to adhirasam. This study shows that the individual inoculation of the isolates of $B$. subtilis subsp. subtilis, B. tequilensis and B. siamensis as a starter culture in the preparation of adhirasam was acceptable to consumers. Thus these isolates can be recognized as suitable starter cultures for fermentation of adhirasam dough. In future, the impact of the inoculation of Bacillus spp. on the stabilization and quality characteristics, especially accumulation of antioxidants and bacteriocins, of adhirasam should be investigated.

\section{Acknowledgement}

This study was supported by Tamil Nadu Agricultural University, Coimbatore, Tamil Nadu, India. The authors thank the assistance rendered by V. Janahiraman and $\mathrm{N}$. Arun Kumar in laboratory experiments and statistical analysis.

\section{References}

Agaliya PJ, Jeevaratnam K (2013) Molecular characterization of lactobacilli from fermented idli batter. Braz J Microbiol 44:1199-1206.

Aidoo KE, Nout MJR, Sarkar PK (2006) Occurrence and function of yeasts in Asian indigenous fermented foods. FEMS Yeast Res 6:30-39.

Benson HJ (2002) Microbiological applications. McGraw Hill, Boston.

Brandt MJ (2007) Sourdough products for convenient use in baking. Food Microbiol 24:161-164.

Chand K, Singh A, Kulshrestha M (2012) Jaggery quality effected by hilly climatic conditions. Indian J Trad Knowledge 11:172-176.

Chantawannakul P, Oncharoen A, Klanbut K et al. (2002) Characterization of proteases of Bacillus subtilis strain 38 isolated from traditionally fermented soybean in Northern Thailand. Sci Asia 28:241-245.

Chen T, Liu WX, Fu J et al. (2013) Engineering Bacillus subtilis for acetoin production from glucose and xylose mixtures. $\mathrm{J}$ Biotechnol 168:499-505.

Choi JM, Kim JH, Cho EJ (2010) Protective activity of purple sweet potato extract-added soymilk fermented by Bacillus subtilis against oxidative stress. Food Sci Biotechnol 19:457-462.

Cho MJ, Lee JY, Kim JH (2014) Microbial and physiochemical properties of Cheonggukjang fermented using Bacillus strains with antibacterial or antifungal activities. Food Sci Biotechnol 23:1525-1532.

Decock P, Cappelle S (2005) Bread technology and sourdough technology. Trends in Food Sci Technol 16:113-120.

Gerhardt P, Murray RGE, Wood WA et al. (1994) Methods for General and Molecular Bacteriology. American Society for Microbiologym Washington, DC.

Hong Y, Jung HJ, Kim HY (2012) Aroma characteristics of fermented Korean soybean paste (Doenjang) produced by $\mathrm{Ba}$ - cillus amyloliquefaciens Food Sci Biotechnol 21:11631172 .

Hosoi T, Kiuchi K (2004) Production and probiotic effects of Natto. In: Bacterial spore formers: probiotics and emerging applications. Ricca E, Henriques AO, Cutting SM (eds) Horizon Bioscience. Wymondham, UK, pp 143-154.

Kelly WJ, Asmundson RV, Harrison GL et al. (1995) Differentiation of dextran- producing Leuconostoc strains from fermented rice cake (puto) using pulse field electrophoresis. Int J Food Microbiol 26:345-352.

Kim YS, Kim MC, Kwon SW et al. (2011) Analyses of bacterial communities in meju, a Korean traditional fermented soybean bricks, by cultivation-based and pyrosequencing methods. J Microbiol 49:340-348.

Larmond E (1977) Laboratory Methods for Sensory Evaluation of Foods. Publication No. 1673. Department of Agriculture, Ottawa, Canada.

Lee NK, Kim SY, Choi SY et al. (2013) Probiotic Bacillus subtilis KU201 having antifungal and antimicrobial properties isolated from kimchi. Food Sci Biotechnol. 22:1-5.

Marshall E, Mejia D (2011) Essentials of fermentation. In: Industrialization of Indigenous Fermented Foods Traditional Fermented Food Beverages for Improved Livelihoods. FAO, Rome pp 42-51.

Meer RR, Baker FW, Bodyfelt FW et al. (1991) Psychrotrophic Bacillus spp. in fluid milk products - A review. J Food Protect 54:969-979.

Park JW, Lee NK, Kim BY et al. (2010) Characterization of traditionally fermented Korean soybean paste,eoyukjang, and isolation of its microorganisms. Food Sci Biotechnol 19:425-430.

Sarkar PK, Tamang JP, Cook PE et al. (1994) Kinema - a traditional soybean fermented food: Proximate composition and microflora. Food Microbiol 11:47-55.

Soni SK, Sandhu DK (1991) Role of yeast domination in Indian idli batter fermentation. World J Microbiol Biotechnol 7:505-507.

Soni SK, Sandhu DK, Vilkhu KS (1985) Studies on dosa - an indigenous Indian fermented food: Some biochemical changes accompanying fermentation. Food Microbiol 2:175-181.

Tamang JP (1999) Development of pulverized starter for kinema production. J Food Sci Technol 36:475-478.

Tamang JP, Tamang N, Thapa S et al. (2012) Microorganisms and nutritional value of ethnic fermented foods and alcoholic beverages of North East India. Indian J Trad Knowledge $1: 17-25$

Terzic-Vidojevic A, Tolinacki M, Nikolic M et al. (2009) L Phenotypic and genotypic characterization of lactic acid bacteria isolated from Azerbaijani traditional dairy products. Afr J Biotechnol 8:2576-2588.

Yonzan H, Tamang JP (2013) Optimization of traditional processing of Selroti, a popular cereal based fermented food. J Sci Ind Res 72:43-47.

Zheng Y, Zheng XW, Han BZ et al. (2013) Monitoring the ecology of Bacillus during Daqu incubation, a fermentation starter, using culture- dependent and culture- independent methods. J Microbiol Biotechnol 23:614-622.

Associate Editor: Maricê Nogueira de Oliveira

All the content of the journal, except where otherwise noted, is licensed under a Creative Commons License CC BY-NC. 